\title{
Splanchnic net balance of oxygen and metabolites in response to mesenteric vein infusion of ammonia in sheep*
}

\author{
M.I. Recavarren'1, M.J. Del Sole ${ }^{2}$ and G.D. Milano \\ Departamento de Fisiopatología, Facultad de Ciencias Veterinarias, \\ Universidad Nacional del Centro, Campus Universitario \\ 7000, Tandil, Buenos Aires, Argentina
}

\begin{abstract}
In order to simulate daily episodes of high ammonia $\left(\mathrm{NH}_{4}^{+}\right)$absorption associated with the intake of diets with high content of non-protein $\mathrm{N}$ or rapidly rumen degradable protein, four wethers $(42 \pm 3.4 \mathrm{~kg}$ BW), surgically fitted with indwelling catheters in the posterior aorta and splanchnic veins, were infused

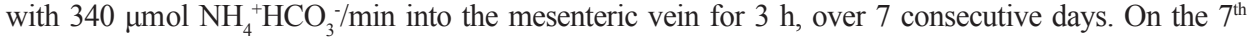
day, net mass transfers of $\mathrm{NH}_{4}^{+}$, urea, glucose, lactate, $\mathrm{B}-\mathrm{OH}$-butyrate and oxygen were measured across portal-drained viscera (PDV), liver and splanchnic tissues during the last 90 min of the $\mathrm{NH}_{4}^{+}$infusion $\left(\mathrm{NH}_{4}^{+}\right.$treatment, $\left.\mathrm{AT}\right)$. Measurements were repeated on the following day, after withdrawal of the $\mathrm{NH}_{4}^{+}$ infusion (Control treatment, CT). $\mathrm{NH}_{4}^{+}$infusion increased liver $\mathrm{NH}_{4}^{+}$uptake $(+396 \mu \mathrm{mol} / \mathrm{min}$; sed, 72 ; $\mathrm{P}=0.04)$ and urea production $(+152 \mu \mathrm{mol} / \mathrm{min}$; sed, $55 ; \mathrm{P}=0.14)$, and oxygen consumption by the liver $(+151 \mu \mathrm{mol} / \mathrm{min}$; sed, $6 ; \mathrm{P}=0.002)$, the PDV $(+224 \mu \mathrm{mol} / \mathrm{min}$; sed, 56 ; $\mathrm{P}=0.03)$ and the splanchnic tissues $(+352 \mu \mathrm{mol} / \mathrm{min}$; sed, $57 ; \mathrm{P}=0.009)$. Net mass transfers of glucose, lactate and $\mathrm{B}-\mathrm{OH}-$ butyrate across the PDV and the liver, and the acid-base status of the animals were unchanged.
\end{abstract}

KEY WORDS: ammonia, urea, glucose, liver, energy expenditure, sheep

\section{INTRODUCTION}

In ruminants, a high proportion of the dietary $\mathrm{N}$ is absorbed as $\mathrm{NH}_{4}^{+}$. The liver removes all the $\mathrm{NH}_{4}^{+}$absorbed and then converts it to urea. $\mathrm{NH}_{4}^{+}$metabolism could alter both liver energy expenditure and glucose production, but there is a controversy about the intensity and the sign (in the latter case) of these effects. In addition, it is unknown whether liver metabolism of other energy metabolites could also be altered. The objective of the present experiment was to examine the response of hepatic,

\footnotetext{
${ }^{*}$ Research Project PICT08-03881, ANPCyT, Argentina

${ }^{1}$ Recipient of Research Scholarships from ANPCyT and CICPBA, Argentina

${ }^{2}$ Recipient of a Research Scholarship from CICPBA, Argentina

${ }^{1}$ Corresponding author: e-mail: mireca@vet.unicen.edu.ar
} 
portal-drained viscera (PDV) and splanchnic net mass transfers of $\mathrm{NH}_{4}^{+}$, glucose, urea, lactate, $\beta-\mathrm{OH}-$ butyrate and oxygen to a $3-\mathrm{h} \mathrm{NH}_{4}^{+}$infusion into the mesenteric vein, administered during $7 \mathrm{~d}$ in order to simulate daily episodes of high $\mathrm{NH}_{4}^{+}$absorption associated with the intake of diets with high concentration of non-protein $\mathrm{N}$ or rapidly rumen degradable protein.

\section{MATERIAL AND METHODS}

\section{Animals, diet and design}

Four Corriedale wethers $(42 \pm 3.4 \mathrm{~kg} \mathrm{BW})$, surgically prepared with indwelling catheters in the posterior aorta, portal, hepatic and mesenteric veins, were housed in individual pens $\left(2.6 \mathrm{~m}^{2}\right)$ and fed $450 \mathrm{~g} / \mathrm{d}$ of lucerne hay plus $360 \mathrm{~g} / \mathrm{d}$ of cracked maize (8.1 MJ ME/d; $16.0 \mathrm{~g} \mathrm{~N} / \mathrm{d}$ ) in 4 equal portions, at 0:30, 6:30, 12:30 and 18:00 h, during 4 weeks, using automatic feeders. Water was offered ad libitum. Throughout the last week, at $8: 30 \mathrm{~h}$, a solution of $900 \mathrm{mM} \mathrm{NH}_{4}^{+} \mathrm{HCO}_{3}^{-}$was infused into the mesenteric vein for $3 \mathrm{~h}\left(340 \mu \mathrm{mol} \mathrm{NH}{ }_{4}^{+} / \mathrm{min} ; 8.1 \mu \mathrm{mol} \mathrm{NH}{ }_{4}^{+} / \mathrm{kgBW} / \mathrm{min}\right)$. On the $7^{\text {th }}$ day, a solution containing $0.1 \mathrm{M} \mathrm{Na} p$-aminohippuric acid $(p \mathrm{AH}), 0.05 \mathrm{M} \mathrm{Na}$ phosphate buffer ( $\mathrm{pH} 7.4$ ) and 460 UI heparin/g (APH solution) was also infused into the mesenteric vein $(0.36 \mathrm{~g} / \mathrm{min})$ during the last $135 \mathrm{~min}$ of the $\mathrm{NH}_{4}^{+} \mathrm{HCO}_{3}^{-}$ infusion, in order to determine the portal and hepatic blood flow $\left(\mathrm{NH}_{4}^{+}\right.$treatment, AT). On the next day, the $\mathrm{NH}_{4}{ }^{+} \mathrm{HCO}_{3}{ }^{-}$infusion was withdrawn and only the $\mathrm{APH}$ solution was infused at identical times (Control treatment, CT).

\section{Samples and analysis}

In both treatments, 45 min after the start of the infusion of the APH solution, two simultaneous blood samples were continuously withdrawn from the aorta and the portal and hepatic veins over $90 \mathrm{~min}(0.17 \mathrm{ml} / \mathrm{min})$. The collection lines were allowed to pass through ice-cold water and the blood samples were collected directly into $10 \mathrm{ml}$ syringes stored in ice-cold water. Samples were carefully mixed and analysed for blood $\mathrm{pO}_{2}, \mathrm{pCO}_{2}$ and $\mathrm{pH}$ immediately after collection, using a Blood Gas Analyser. The packed cell volume, blood haemoglobin and $p$ AH concentration were analysed as described by Milano et al. (2000). A portion of blood was centrifuged $\left(1000 \mathrm{~g} ; 4^{\circ} \mathrm{C}\right)$, and the plasma was processed for determination of $\mathrm{NH}_{4}^{+}$, urea and glucose (Milano et al., 2000), lactate (Lactate, Randox $^{\circledR}$ ) and $\mathrm{B}-\mathrm{OH}-$ butyrate (Ranbut, Randox ${ }^{\circledR}$ ). Infusions and blood collections were performed with peristaltic pumps.

\section{Calculations and statistics}

Blood flow and net mass transfers of metabolites and oxygen across the liver, the PDV and the splanchnic tissues were calculated as described by Milano et al. (2000). The data were analysed by ANOVA, with animals and treatment as main factors. 


\section{RESULTS AND DISCUSSION}

The results are shown in Table 1. PDV and liver data represent the average of 3 data points per treatment because the portal vein catheter lost patency in one of the animals.

Table 1. Mass transfers of $\mathrm{NH}_{4}^{+}$, glucose, urea, lactate, $\beta$-OH-butyrate and oxygen $(\mu \mathrm{mol} / \mathrm{min})$ across the portal-drained viscera (PDV), the liver and the splanchnic tissues, and arterial base excess $(\mathrm{mM})$ and $\mathrm{pH}$ in response to a 3- $\mathrm{h}$ infusion of $340 \mu \mathrm{mol} \mathrm{NH}_{4}{ }^{+} \mathrm{HCO}_{3}^{-} / \mathrm{min}$ into the mesenteric vein, administered for $7 \mathrm{~d}$, in wethers

\begin{tabular}{lcccl}
\hline & $\mathrm{CT}$ & $\mathrm{AT}$ & $\mathrm{Sed}$ & $\mathrm{P}$ \\
\hline PDV & 214 & 650 & 44 & 0.013 \\
$\mathrm{NH}_{4}^{+}$ & 178 & 51 & 41 & 0.11 \\
glucose & -61 & 63 & 194 & $\mathrm{NS}$ \\
urea & 81 & 95 & 29 & $\mathrm{NS}$ \\
lactate & 46 & 143 & 81 & $\mathrm{NS}$ \\
ß-OH-butyrate & -1110 & -1334 & 56 & 0.029 \\
oxygen & & & & \\
Liver & -260 & -656 & 72 & 0.04 \\
$\mathrm{NH}_{4}^{+}$ & 199 & 210 & 9 & $\mathrm{NS}$ \\
glucose & 289 & 441 & 55 & 0.14 \\
urea & -95 & -88 & 11 & $\mathrm{NS}$ \\
lactate & 71 & 72 & 6 & $\mathrm{NS}$ \\
ß-OH-butyrate & -1188 & -1339 & 6 & 0.002 \\
oxygen & & & & \\
Splanchnic tissues & -2608 & -2960 & 57 & 0.009 \\
$\quad$ oxygen & 4.17 & 5.52 & 0.42 & 0.11 \\
Arterial base excess & 7.498 & 7.483 & 0.017 & $\mathrm{NS}$ \\
Arterial pH & & & & \\
\hline
\end{tabular}

$\mathrm{n}=6$, except for splanchnic tissues $(\mathrm{n}=8)$. Positive and negative values indicate net production and net uptake of the metabolite across the relevant organ, respectively

$\mathrm{NH}_{4}^{+}$

In both treatments, liver $\mathrm{NH}_{4}^{+}$uptake was higher than $\mathrm{PDV} \mathrm{NH}{ }_{4}^{+}$absorption. The difference between treatments in liver $\mathrm{NH}_{4}^{+}$uptake $(396 \mu \mathrm{mol} / \mathrm{min} ; \mathrm{P}=0.04)$ was similar to the mean $\mathrm{NH}_{4}^{+}$infusion rate $(340 \mu \mathrm{mol} / \mathrm{min})$.

\section{Glucose}

There was a trend for lower absorption or higher utilization of glucose by the PDV in AT $(130 \mu \mathrm{mol} / \mathrm{min} ; \mathrm{P}=0.11)$. Hepatic glucose production was not significantly different between treatments. Blood $\mathrm{BE}$ and $\mathrm{pH}$ were not altered by $\mathrm{NH}_{4}^{+} \mathrm{HCO}_{3}^{-}$infusion in the current experiment, suggesting that the enhanced glucose production observed in previous experiments with sheep during $\mathrm{NH}_{4}^{+} \mathrm{Cl}^{-}$ infusion into the mesenteric vein $\left(30 \mu \mathrm{mol} \mathrm{NH}_{4}{ }^{+} \mathrm{Cl}^{-} / \mathrm{kg} \mathrm{BW} / \mathrm{min}\right.$; Barej et al., 
1987; $6.7 \mu \mathrm{mol} \mathrm{NH}{ }_{4}^{+} \mathrm{Cl} / \mathrm{kgBW} / \mathrm{min}$; Milano et al., 2001), might have been linked to a $\mathrm{NH}_{4}^{+} \mathrm{Cl}^{-}$-induced metabolic acidosis.

\section{Urea, lactate and $\beta$-OH-butyrate}

The differences between treatments in mass transfers of urea, lactate and

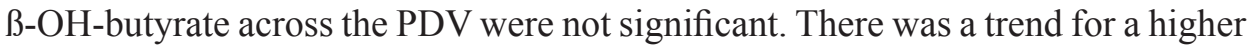
hepatic urea production in AT $(+303 \mu \mathrm{mol}$ urea-N/min; $\mathrm{P}=0.14)$. This increase represents a recovery of $77 \%$ of the $\mathrm{N}$ infused. There were no differences between treatments in liver lactate uptake or $\beta-\mathrm{OH}-$ butyrate production.

\section{Oxygen}

PDV, liver and splanchnic oxygen consumption was significantly higher in AT (224, 151 and $352 \mu \mathrm{mol} / \mathrm{min}$, respectively). Liver oxygen consumption increased by $0.39 \mathrm{~mol} / \mathrm{mol} \mathrm{NH}_{4}^{+}$removed or $0.49 \mathrm{~mol} / \mathrm{mol}$ urea-N produced, these ratios being slightly higher than the stoichiometric ratios accepted for urea synthesis $(0.33 \mathrm{~mol} /$ urea-N; Stryer, 1988). Milano et al. (2000) found that the liver oxygen consumption increased by $0.69 \mathrm{~mol} / \mathrm{mol} \mathrm{NH}_{4}^{+}$removed or $0.61 \mathrm{~mol} / \mathrm{mol}$ urea-N produced $(\mathrm{P}=0.13)$ during continuous infusion of $400 \mu \mathrm{mol} / \mathrm{min}$ of $\mathrm{NH}_{4}^{+} \mathrm{HCO}_{3}^{-}$into the mesenteric vein of wethers for 4 days. When extrapolated to the $180 \mathrm{~min}$ of the $\mathrm{NH}_{4}^{+}$infusion, the increment in splanchnic oxygen consumption observed in the current experiment amounts to $63.4 \mathrm{mmoles}$ or $29 \mathrm{KJ}\left(0.352 \mathrm{mmol} / \mathrm{min} \times 180 \mathrm{~min} \times 460 \mathrm{KJ} / \mathrm{mmol} \mathrm{O}_{2}\right)$, i.e. the equivalent of $1 \%$ of the daily ME intake destined to deposition (based on a daily $\mathrm{EM}$ intake of 8.2 MJ and 5.3 MJ ME/d of maintenance energy requirements).

\section{CONCLUSIONS}

The $3 \mathrm{~h}$ infusion of $\mathrm{NH}_{4}^{+} \mathrm{HCO}_{3}^{-}$for $7 \mathrm{~d}$, increased $\mathrm{NH}_{4}^{+}$liver uptake, with a consequently higher urea production, and oxygen consumption by the liver, the PDV and the splanchnic tissues. No changes were observed in hepatic net mass transfers of glucose, lactate and $\beta-\mathrm{OH}-b u t y r a t e$ or in the acid-base status of the animals.

\section{REFERENCES}

Barej W., Ostaszewski P., Pierzynowski G., 1987. Urea and glucose formation in ovine liver after ammonia and lactate loading in vivo. Ann. Rech. Vet. 18, 29-34

Milano G.D., Hotston Moore A., Lobley G.E., 2000. Influence of hepatic ammonia removal on ureagenesis, amino acid utilisation and energy metabolism in the liver. Brit. J. Nut. 83, 307-315

Milano G.D., Lobley G.E., 2001. Liver N movements during short-term infusion of high levels of ammonia into the mesenteric vein. Brit. J. Nutr. 86, 507-513

Milano G.D., Recavarren M.I., Del Sole M.J., Gonda H.L., Bakker M.L., 2001. Cambios en el flujo neto esplácnico de glucosa en respuesta a la infusión mesentérica de $\mathrm{NH}_{4}^{+}$en borregos alimentados con heno de alfalfa y grano de maíz. Rev. Arg. Prod. Anim. 21, Suppl. 1, 59-60

Stryer L., 1988. Biochemistry. W. H. Freeman and Company, New York, pp. 495-515 